\title{
Application of an Optimization Model for Assessing the Performance of Water Appropriation in Iraq
}

\author{
Ahmed A. Aljanabi ${ }^{1}$, Larry W. Mays ${ }^{1} \&$ Peter Fox $^{1}$ \\ ${ }^{1}$ School of Sustainable Engineering and the Built Environment, Arizona State University, Tempe, AZ, USA \\ Correspondence: Larry W. Mays, School of Sustainable Engineering and the Built Environment, Arizona State \\ University, Tempe, AZ, USA. E-mail: Mays@asu.edu
}

Received: January 25, 2018

Accepted: February 23, $2018 \quad$ Online Published: February 28, 2018

doi:10.5539/enrr.v8n1p105

URL: https://doi.org/10.5539/enrr.v8n1p105

\begin{abstract}
The magnitude of water resources shortages in the Middle East represents an important factor in the stability of the region and it is a vital element in protecting sustained economic development in the region. This investigation addresses the ongoing challenge of water governance in Iraq by examining how profitability, at both the farm and basin levels, is affected by various water appropriation systems. Farmland irrigation in Iraq was evaluated using three water appropriation systems; upstream (UPR), downstream (DPR) and proportional (PSR) sharing rule. Their impacts on farm income under normal, dry, and drought water supply scenarios were evaluated using an irrigation water model coupled with a nonlinear programming (NLP) optimization model. As compared to UPR, PSR provided a $32 \%$ and $75 \%$ increase in total farm income for the Tigris River under dry and drought supply conditions, respectively. As compared to DPR, PSR provided a $47 \%$ and $83.5 \%$ increase in total farm income for the Euphrates River under dry and drought supply conditions, respectively.
\end{abstract}

Keywords: Optimization, agriculture, water allocation, drought, shadow prices

\section{Introduction}

Iraq is located in the eastern part of the arid and semi-arid Middle East. The country's climate tends to have temperatures of $43^{\circ} \mathrm{C}$ during the months of July and August and drop-down to an average of $16-20^{\circ} \mathrm{C}$ during the winter (Al-Ansari, 2013, Al-Ansari \& Knutsson, 2011). In addition, the Tigris and Euphrates Rivers form the primary sources of fresh water for Iraq (Figure 1). The average annual flow for the Tigris River from 2003 to 2014 has been estimated as 36.4 billion $\mathrm{m}^{3} / \mathrm{yr}$. Most of the Tigris River water and its tributaries originate in Turkey (56\%) followed by Iran (12\%) and the remaining 32\% from sources inside Iraq (Table 1). During the period of 1933-2012, the Tigris's River experienced significant fluctuations in its annual water income and a noticeable repetition of water shortage since 1999. Furthermore, the Euphrates River sources originate in Turkey (88\%) followed by Syria (9\%) and Iraq (3\%). The Euphrates River experienced significant water shortages from 2009 to 2014. These two rivers also experience significant water demands upstream of Iraq. Combining the recent situation of water supply decreases and increasing demands in Turkey and Iraq, more severe shortages in surface water resources are to be expected in the future, particularly if the effects of climate change are considered (Voss et al., 2013).

In Iraq, the planning and construction of new irrigation and flood control systems by the Board of Development began in 1950. As a result, numerous dams, canal systems, irrigation projects and flood control structures were constructed on the river systems inside Iraq (UNEP, 2001; Iraqi Ministry of Water Resources, 2013). These structures had positive impacts on the receiving agricultural lands and the installation of tile drainage systems helped develop and improve agricultural lands providing an important impact on the country's economy.

The Southeastern Anatolia Project (GAP) in Turkey began in 1970 and will consist of 22 dams on both the Tigris and Euphrates Rivers. This project has reduced the flow of water to Iraq by approximately $50 \%$ and also increased the salinity of the water entering Iraq. The combination of reduced water flows, reduced rainfall, and population growth in Iraq resulted in periods of severe water shortages in 2007- 2009. There was a steep decline in agricultural productivity in the highly populated areas along the Euphrates and Tigris river basins (Shean, 2008). Iraq's crop production was reduced to one half of its usual rate of production and many farmers abandoned their agricultural lands. Consequently, food imports had to increase and the majority of food is currently imported into Iraq resulting in elevated costs to consumers (UNDP, 2009). 


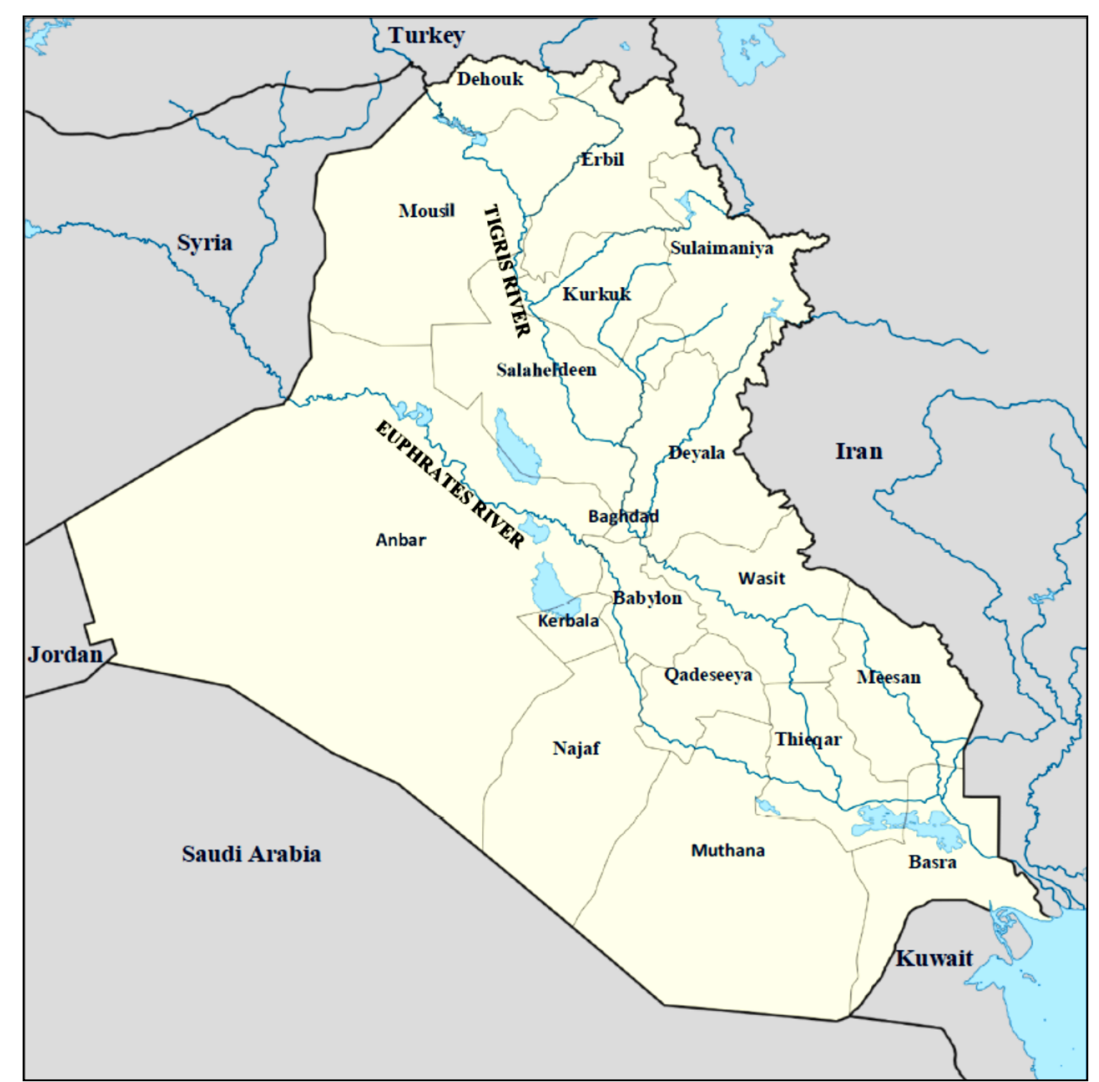

Figure 1. Iraq provinces and surface water system (Nord Nord West License, 2016)

Table 1. Tigris River and its tributaries average annual water flows

\begin{tabular}{|c|c|c|c|c|c|}
\hline \multirow{2}{*}{ Tigris River and its Tributaries } & \multirow{2}{*}{ Total Length (km) } & \multirow{2}{*}{$\begin{array}{c}\text { Total Area } \\
\mathrm{km}^{2} \\
\end{array}$} & \multirow{2}{*}{ Annual Water Flows (Billion $\mathrm{m}^{3}$ ) } & \multicolumn{2}{|c|}{ Annual Water Flow (\%) } \\
\hline & & & & Inside Iraq & Outside Iraq \\
\hline Tigris River & 1900 & 46700 & 19.43 & - & 1 \\
\hline Feesh Khabour & 160 & 6270 & 2.1 & 0.58 & 0.42 \\
\hline Greater Zab & 473 & 26470 & 14.32 & 0.58 & 0.42 \\
\hline Lesser Zab & 456 & 22250 & 7.07 & 0.64 & 0.36 \\
\hline Adhaim & 220 & 10680 & 0.7 & 1.00 & - \\
\hline Deyala & 386 & 3200 & 5.86 & 0.41 & 0.59 \\
\hline Total & & & 49.48 & 0.32 & $\begin{array}{c}\text { Turkey } 56 \% \\
\text { Iran } 12 \% \\
\end{array}$ \\
\hline
\end{tabular}

Since 2014, in addition to internal instability due to political conflicts that have directly affected the country's security and economy, Iraq has been subjected to several external attacks from what is known as the Islamic State in Iraq and Syria (ISIS). These conflicts affected the control of the waters in the Tigris and Euphrates rivers while ISIS controlled the Falluja Barrage on the Euphrates River and Mosul Dam on the Tigris River. Furthermore, ISIS also threatened many other important hydraulic structures such as Haditha Dam on the Euphrates River close to the Syrian border. These threats generated instability in water supplies and in their associated agricultural production as the Iraqi government could not ascertain control of the water supplies. Consequently, severe water shortages lasted for more than two years in many regions which were irrigated by the Euphrates River to the south of Baghdad. Furthermore, major issues and local conflicts occurred which reflected negatively on the entire water system in Iraq. Fortunately, in 2016-2017 the Iraqi forces and their allies were capable to combat and defeat ISIS in many regions in Iraq, allowing the Iraqi government to control the water supply.

Currently, there remains a serious threat to the Mosul Dam due to a potential foundation failure. This threat has been known for an extended period of time. Iraqi authorities have attempted to stabilize the foundation of the dam using grout. A lack of funding and the dangerous security conditions around the Mosul Dam have made it 
difficult to completely stabilize the dam. A dam breach would cause flooding and increase downstream water shortages. In late 2016, efforts to solve the problem at the Mosul Dam were resumed by the Iraqi government which created hope in recovering the dam to its full functionality.

\subsection{Objective}

Combining the reduction in water supply, the recent political conflicts, in addition to future predictions based on global warming, increased severe water shortages are to be expected in Iraq's surface water resources. Serious and time responsive measures should be adopted in order to overcome this potential problem. Regional cooperation and coordination should be taken by the decision makers to implement practical and applicable water management strategies. So, the agricultural water allocation optimization model implemented in this study, through maximizing the net farm benefit, was modified and applied to provide guidance for the future water authorities and to sustain water in Iraq's future.

\subsection{Optimization for Water Allocation Modeling}

Water allocation models have been developed for regions with climates similar to Iraq using a variety of methodologies. Burton (1994) developed a Computer Aided and Management Simulation of Irrigation Systems model (CAMSIS) to simulate farm income by using different water allocation rules and polices which were adopted under water shortage or drought scenarios in East Africa. Paul et al. (2000) used a multi-level approach to solve problems related to seasonal and intra-seasonal irrigation water resources allocation in a semiarid region of Indian Punjab considering the competition of the crops in a season, both for irrigation water and area of cultivation. An agricultural water allocation system model using linear programming was developed by Salman et al. (2001) for analysis of inter-seasonal irrigation water allocation and their effects on the net farm income. The function of the model is to serve as a decision-making tool for planners of agricultural production on both local and regional levels. Shangguan et al. (2002) presented an irrigation water allocation optimization model using multiple water resources allocation and their results demonstrated that obstacles in dynamic programming with multiple dimensions could be overcome. Brown et al. (2002) used an AQUARIUS model developed to evaluate temporal and spatial allocation of flows among competing water uses in a river. Babel et al. (2005) introduced the interactive Integrated Water Allocation Model (IWAM) to aid in decision-making for water use by considering socio-economic, environmental and technical factors using three computational modules for reservoir operation, economic analysis and water allocation. Sadegh et al. (2010) proposed a methodology based on Shapely Games to be used in water resources allocation among different users for the Karoon River basin in Iran with the goal of developing an equity standard to increase the total net benefit of the system.

A stochastic nonlinear programming model with multiple objectives was used by You et al. (2011) to aid in multi-objective decision-making considering the Haihe River as a case study. An Inexact Rough-interval Fuzzy Linear Programming IRFLP model was constructed to make a comparison between the IRFLP model and an interval-valued linear programming model for water allocation to provide more conveniences for decision makers. The IRFLP shows distinction in handling the interaction between dual intervals of highly uncertain parameters, as well as their joint impact on the system ( $\mathrm{Lu}$ et al., 2011). A water resources allocation optimization model (Wang et al., 2015) using multi-objective programming was applied on water deficient of Haihe River basin by embedding land use as a constraint on water allocation. Oxley et al. (2016) developed a model that defines the net economic benefits calculated in terms of both use and non-use values and sustainability in terms of the risks to water supplies and riverine ecological, environmental and hydrological integrity. An optimization model maximizing the sustainable net economic benefit over a long-term planning horizon was applied by Oxley and Mays (2016) to Prescott Active Management Area. The model evaluates four scenarios to test the validity of the developed model and to provide examples of its potential application.

Fotakis and Sidiropoulos (2012) developed a multi-objective evolutionary algorithm to simultaneously solve the problem of land use planning and resource allocation which performs optimization on a cellular automaton domain, applying suitable transition rules on the individual neighborhoods. Fang et al. (2013) presented a comprehensive solution for water resources allocation in the Wuwei Basin and they concluded that the model can effectively balance the benefits among all regions and sections. Vaghefi et al. (2013) linked the soil and water assessment tool (SWAT) and the generic river basin management decision support system (MODSIM) for water allocation in the Karkheh river basin. Their analyses indicate that it is possible to use changes in cropping patterns as an effective tool to adapt to the negative impacts of climate change.

Salman et al. (2014) presented a methodology to maximize the net farm income in Iraq by producing different types of crops. Four water right (allocation) systems were considered: upstream priority, downstream priority, proportional sharing of shortage, and unrestricted water trading. They considered three water supply scenarios 
including: normal, dry and drought supply conditions. Dry conditions were $50 \%$ of normal conditions and drought conditions were $20 \%$ of normal conditions. The various conditions were compared in terms of their capacity to minimize losses in net farm water-related income.

One of the limitations in the work by Salman et al. (2014) was that the Tigris and Euphrates Rivers were considered as one individual basin inside Iraq for irrigation in thirteen provinces. Water managers in Iraq consider the two rivers as two separate basins which irrigate fifteen provinces. Thus, in order to provide water managers more useful information, the model developed by Salman et al. (2014) was modified considering the two rivers as two separate basins which irrigate fifteen provinces. Furthermore, the Salman et al. (2014) model considered unrestricted water trading as one of the water allocation priorities. In Iraq, a water trading strategy is inapplicable due to Iraq's recent political, geographical, and social composition as well as other religious considerations. Therefore, water trading was not considered in the adopted model.

The optimization model utilized in this study was modified and applied to provide guidance for the future water authorities and to sustain water in Iraq's future by using recent water resource data. Based upon the history of Iraq's water resources systems and provincial distribution, changes were made to the mentioned model by Salman et al. (2014) in order to satisfy the current conditions in Iraq. These changes affected some of the water distribution systems and the irrigated provinces for each river. Most of the data which were used in the original model was from the year 2012 .

The model application in this research improves upon the excellent work previously done by Salman et al. (2014). Improvements include: making the model more accurate and applicable by reflecting the Tigris and Euphrates River basins as separate basins, and the use of more recent data to reflect the current irrigation and agricultural conditions inside Iraq. These modifications were made to reflect the experience with Iraq's recent water conditions. These changes can be summarized as follows:

1) In comparison to Salman et al. (2014), who considered the Tigris and Euphrates Rivers as one individual basin in Iraq, this modeling effort considers the Rivers as two separate basins. This change was done to the original model in order to satisfy Iraq's current conditions and to investigate a different approach. The updated model optimizes each of the two river basins separately, which is how water is managed in Iraq.

2) The second modification is to allocate the water of the two rivers over 17 agricultural demand nodes inside Iraq (Table 2) in contrast to Salman et al. (2014) who considered only 13 irrigation provinces (nodes) to be irrigated by only one river basin.

3) The updated model considers The Tigris River to irrigate eight provinces (nodes) which form the majority of the eastern part of Iraq alongside with its flow path all the way from the north to the south of Iraq. While the Euphrates River basin irrigates nine provinces (nodes) along with its flow path at the western parts of Iraq starting at its entrance at the Iraqi-Syrian border to the Arabian (Persian) Gulf south of Iraq. Both Baghdad and Basra were divided into two sections because they are irrigated from the two rivers at the same time. The eastern parts, Baghdad-A and Basra-A, are irrigated from The Tigris River, while the western parts, Baghdad-B and Basra-B, are irrigated from The Euphrates River. Thus, there are seventeen irrigated nodes in contrast to the thirteen provinces (nodes) used by Salman et al. (2014).

4) The updated model includes updated data to match the most recent conditions in Iraq. These data were observed from Iraqi Central of Statistical Organization (ICSO) (2015) which include crop production rates, agricultural land per crop, production cost per crop, and associated crop prices.

Table 2. Irrigated land in production by province (ICSO, http://cosit.gov.iq/ar/agri-ind)

\begin{tabular}{ccccccccccc}
\hline & \multicolumn{9}{c}{ Tigris River } \\
Province & Mosul & Kurkuk & Salaheldeen & Deyala & Baghdad-A & Wasit & Mesan & Basrah-A \\
\hline Estimated Irrigated Area (1000 ha) & 94.08 & 189.29 & 221.02 & 172.83 & 52.75 & 258.51 & 111.86 & 29.36 \\
\hline & \multicolumn{7}{c}{ Euphrates River } \\
Province & Anbar & Baghdad-B & Babylon & Karbala & Najaf & Qadeseeya & Muthana & Thieqar & Basrah-B \\
\hline Estimated Irrigated Area (1000 ha) & 126.25 & 41.19 & 132.28 & 10.38 & 50.08 & 160.72 & 1.93 & 51.33 & 23.43 \\
\hline
\end{tabular}

\section{Data for Optimization Model}

The required data used in the optimization model is listed in Tables 1-4. Portions of the data on land in production, crop yields, prices, costs of production, and net farm income per unit land by province for the years 
2010-2014, were adopted from select sources including the Iraqi Central Statistical Organization (ICSO, 2015), and Salman et al. (2014). Others were secured from specific Iraqi institutions including the Ministry of Water Resources and the Ministry of Agriculture. The Tigris and Euphrates Rivers' annual flows were estimated to be 43-52.6 billion $\mathrm{m}^{3} / \mathrm{yr}$ and 28.7-30.5 billion $\mathrm{m}^{3} / \mathrm{yr}$ respectively based on data from the Iraqi Ministry of Water Resources (2013). The year 2006 was taken as the base year for the current analysis because the supply from the river system water used in crop irrigation was a maximum value. This was based on the 2006-2013 historical data from the Iraqi Ministry of Agriculture showing that the highest total amount of irrigated land in production occurred in 2006 (Al-Ansari, 2013). Salman et al., 2014, calculated the river system water use by irrigated crops using the indirect methods described by Allen et al. (1998).

Saleh (2010) considered crop irrigation water requirement (ETc) as about $30 \%$ of the total water supplied by the Tigris-Euphrates system in Iraq. Therefore, almost $70 \%$ of the available surface water inside the country is largely unaccounted for and the exact fate of the water is not certain.

Crop water requirements ETc were adopted from Salman et al. (2014), which were based on water demands to support maximum yield. Crop production costs in US dollar per hectare $(\$ / \mathrm{ha})$ were updated to 2015 values, as presented in Table 3, based on data secured from the Iraqi Ministry of Agriculture. Therefore, these costs are higher than those which were adopted in the original model by Salman et al. (2014). The reason for higher costs include conflicts in Iraq and the rise of all agricultural prices starting from the prices of seeds along with the prices of fuel and fertilizers. The production cost includes soil fertility, weather, and water availability and quality which fluctuated across Iraq. The yield rates of different types of crops in Iraq are provided in Table 4.

Table 3. Crop production costs exclusive of water costs (\$ US per Ha) (ICSO, http://cosit.gov.iq/ar/agri-ind)

\begin{tabular}{cccccccccc}
\hline Crop & Rice & Wheat & Cotton & Sunflower & Maize & Barley & Tomato & Lettuce & Onion \\
Cost $\$$ & 850 & 820 & 1300 & 655 & 900 & 720 & 1300 & 850 & 580 \\
\hline
\end{tabular}

Table 4. Crop yield tons per hectare (proportional to ET) (ICSO, http://cosit.gov.iq/ar/agri-ind)

\begin{tabular}{lccccccccc}
\hline Province & Rice & Wheat & Cotton & Sunflower & Maize & Barley & Tomato & Lettuce & Onion \\
\hline 1-Mousil & 2.89 & 3.05 & 2.40 & 1.33 & 4.40 & 0.90 & 17.90 & 19.97 & 5.89 \\
2-Kurkuk & 2.89 & 3.35 & 2.50 & 2.86 & 5.63 & 2.76 & 5.86 & 15.20 & 4.80 \\
3-Salaheldeen & 2.89 & 2.49 & 0.80 & 1.58 & 3.57 & 1.18 & 12.79 & 15.44 & 2.10 \\
4-Deyala & 2.89 & 3.58 & 1.87 & 1.67 & 2.51 & 2.00 & 27.90 & 21.70 & 11.54 \\
5-Anbar & 4.00 & 2.69 & 0.36 & 2.78 & 2.08 & 0.8 & 14.82 & 23.77 & 9.24 \\
6-Baghdad & 4.00 & 2.61 & 0.58 & 1.45 & 2.26 & 1.21 & 14.60 & 26.18 & 20.13 \\
7-Babylon & 4.04 & 3.15 & 0.94 & 1.69 & 2.88 & 1.78 & 10.50 & 16.32 & 5.32 \\
8-Karbala & 4.00 & 2.35 & 0.50 & 1.50 & 2.66 & 1.55 & 9.48 & 9.07 & 3.30 \\
9-Najaf & 4.88 & 1.39 & 0.50 & 1.50 & 2.47 & 1.36 & 34.65 & 14.69 & 20.69 \\
10-Qadeseeya & 4.70 & 2.37 & 0.40 & 1.50 & 2.54 & 1.74 & 11.38 & 9.74 & 7.05 \\
11-Wasit & 2.89 & 2.81 & 0.50 & 1.33 & 2.58 & 1.28 & 7.12 & 11.91 & 4.40 \\
12-Muthana & 2.51 & 1.34 & 0.50 & 1.50 & 0.00 & 1.03 & 14.10 & 9.50 & 1.00 \\
13-Meesan & 2.20 & 2.17 & 2.42 & 1.33 & 3.40 & 1.41 & 14.44 & 11.45 & 0.01 \\
14-Thieqar & 1.80 & 1.86 & 0.50 & 1.50 & 2.85 & 1.66 & 7.85 & 18.26 & 11.31 \\
15-Basra & 1.70 & 1.98 & 0.50 & 1.50 & 0.88 & 0.87 & 2.97 & 11.45 & 1.00 \\
\hline
\end{tabular}

\section{Optimization Model}

\subsection{Objective}

The purpose of this model is to allocate crops on land in order to maximize the net farm income (Nfi) by determining the optimal amount of land $\left(\operatorname{Ln}_{\mathrm{i}, \mathrm{k}}\right)$ assigned to each crop $(\mathrm{k})$ in each province (i). The ability to generate farm income is constrained by the quantity of water available for agriculture. A mass balance equation was developed for water allocation and then constraints were assigned for the three different water supply scenarios. The optimization model considered eight provinces associated with the Tigris River (Mousil, Kurkuk, Salaheldeen, Deyala, Baghdad-A, Wasit, Meesan, Basra-A) and the nine provinces associated with the Euphrates River (Anbar, Baghdad-B, Babylon, Karbala, Najaf, Qadeseeya, Muthana, Thieqar, Basra-B). 
The objective function is to maximize the total income from the crops $\mathrm{k}=1, \ldots, \mathrm{K}$ in provinces $\mathrm{i}=1, \ldots, \mathrm{I}$, expressed as:

$$
\text { Max Net Farm Income }\left(N f_{i}\right)=\operatorname{Max} \sum_{i} \sum_{k} N b_{i, k}
$$

where $\mathrm{Nb}_{\mathrm{ik}}$ is the total income from crop $\mathrm{k}$ in province $\mathrm{i}$ expressed as

$$
N b_{i, k}=\left(P_{i, k} Y_{i, k}-C_{i, k}\right) L n_{i, k}
$$

where $\mathrm{P}_{\mathrm{ik}}$ is the selling price (\$/ton) of crop $\mathrm{k}$ in province $\mathrm{i} ; \mathrm{Y}_{\mathrm{ik}}$ is the yield of crop $\mathrm{k}$ (tons/ha) in province $\mathrm{i}$; $\mathrm{C}_{\mathrm{ik}}$ is the cost $(\$ / \mathrm{ha})$ of production of crop $\mathrm{i}$ in province $\mathrm{k}$; and $\mathrm{Ln}_{\mathrm{ik}}$ is the land in production (1000 ha/year) of crop $\mathrm{k}$ in province $\mathrm{i}$.

\subsection{Decision Variables and Constraints}

The nonlinear programming (NLP) model contains a number of decision variables which are: water availability $\left(\mathrm{W}_{\mathrm{x}, \mathrm{i}, \mathrm{k}}\right)$ for normal conditions, dry conditions, and drought conditions are $\left(\mathrm{W}_{1, \mathrm{i}, \mathrm{k}}\right),\left(\mathrm{W}_{2, \mathrm{i}, \mathrm{k}}\right)$, and $\left(\mathrm{W}_{3, \mathrm{i}, \mathrm{k}}\right)$ respectively; land assigned $\left(\mathrm{L}_{\mathrm{x}, \mathrm{i}, \mathrm{k}}\right)$ under normal, dry and drought water supply conditions are $\left(\mathrm{L}_{1, \mathrm{i}, \mathrm{k}}\right),\left(\mathrm{L}_{2, \mathrm{i}, \mathrm{k}}\right)$, and $\left(\mathrm{L}_{3, \mathrm{i}, \mathrm{k}}\right)$ respectively.

\subsubsection{Water Availability Conditions/Constraints}

Three water availability conditions $\mathrm{Wu}_{\mathrm{x}}\left(\mathrm{m}^{3}\right)$ for the upstream entrance of each river are included: availability for normal conditions $\mathrm{Wu}_{1}$; availability for dry conditions $\mathrm{Wu}_{2}=0.5 \mathrm{Wu}_{1}$; and availability for drought conditions $\mathrm{Wu}_{3}=0.2 \mathrm{Wu}_{1}$. Subscript $\mathrm{x}=1$ represents the water supply under normal conditions, $\mathrm{x}=2$ is the water supply under dry conditions and $\mathrm{x}=3$ is the water supply under drought conditions.

The sum of the total water assigned for each province under a certain water availability condition must be equal to or less than the total amount of water assigned for all the provinces under the same availability conditions $\left(\mathrm{Wu}_{1}, \mathrm{Wu}_{2}, \mathrm{Wu}_{3}\right)$. Using non-linear constraints written in terms of the decision variables $\mathrm{W}_{\mathrm{x}, \mathrm{i}, \mathrm{k}}$ and $\mathrm{L}_{\mathrm{x}, \mathrm{i}, \mathrm{k}}$, the sum of the total water assigned for each province $\mathrm{i}$ is expressed as:

$$
\sum_{i} \sum_{k} W_{x, i, k} \quad L_{x, i, k} \leq W u_{x} \quad \text { for } \mathrm{x}=1,2,3
$$

where $\mathrm{W}_{\mathrm{x}, \mathrm{i}, \mathrm{k}}$ is the unknown water use $\left(\mathrm{m}^{3} / \mathrm{ha}\right)$ of crop $\mathrm{k}$ in province $\mathrm{i}$ for a certain water supply condition $(\mathrm{x}=1,2$, 3 ) and $\mathrm{L}_{\mathrm{x}, \mathrm{i}, \mathrm{k}}$ is the unknown land (ha) to cultivate crop (i) in province (k) under the same water supply conditions.

\subsubsection{Land in Production Under Various Water Supply Conditions/Constraints}

The total predicted land in production $L p_{x, i}$ for a specific water supply condition per province $\mathrm{i}(1000 \mathrm{ha})$ is the sum of the unknown irrigated land $\mathrm{L}_{\mathrm{x}, \mathrm{i}, \mathrm{k}}$ for each crop $\mathrm{k}$ in each province $\mathrm{i}$ under the same water supply condition $\mathrm{x}$, expressed as

$$
L p_{x, i}=\sum_{k} L_{x, i, k} \quad \text { for } \mathrm{x}=1,2,3 \text { and } \mathrm{i}=1, \ldots, \mathrm{I}
$$

The available irrigable farmland for each province is presented in Table 2 and represents the maximum farmland that could be used in each province.

\subsubsection{Water Rights by Province Constraints}

The percentage of a basin's water rights by province i (policy of water allocation rule) under certain water supply conditions $\left(\mathrm{R}_{\mathrm{x}, \mathrm{i}}\right)$ is evaluated using different priorities based on three distinct water sharing rules: upstream priority rule (UPR), downstream priority rule (DPR), and proportional sharing allocation rules (PSR). The sum of the total water rights percentages $R_{x, i}$ for all provinces under a certain water supply condition $(x=1,2,3)$ must be equal to 1.0 as expressed in terms of the unknown water use $W_{x, i, k}$ and the irrigated land $L_{x, i, k}$ under the same water supply conditions.

$$
R_{x, i}=\frac{\sum_{k}\left(W_{x, i, k} L_{x, i, k}\right)}{W u_{x}}=1.0 \quad \text { for } \mathrm{x}=1,2,3 \text { and } \mathrm{i}=1, \ldots, \mathrm{I}
$$

\subsection{Water Allocation Rules}

\subsubsection{Upstream Priority Rule (UPR)}

The upstream province in the river basin collects its full allocation of water, while the next lower province collects its full allocation of the remaining water as long as water remains in the river system. The remaining water after supplying provinces using the upstream allocation rule with higher priorities $\mathrm{Rsu}_{\mathrm{x}, \mathrm{i}}$, starting from the upstream province traveling to the farthest downstream province under a certain water supply condition $(x=1,2$, $3)$, is defined as:

$$
R s u_{x, i}=\left(W u_{x}-\sum_{k} W_{x, i, k}\right) \quad \text { for } \mathrm{x}=1,2,3 \text { and } \mathrm{i}=1, \ldots, \mathrm{I}
$$




$$
\sum_{k} W_{x, i, k}=0 \quad \text { when } \mathrm{i}=1 \quad \text { for } \mathrm{x}=1,2,3
$$

\subsubsection{Downstream Priority Rule (DPR)}

Under this water allocation rule, the farthest downstream province receives its full amount of water that would occur under a specific water supply condition while the next upper province takes its full amount of remaining water, sequentially moving from the downstream to the upstream provinces. The water allocation, using DPR, is essentially the opposite of UPR, resulting in an almost identical mathematical expression. The remaining water after supplying provinces using DPR with higher priorities $\operatorname{Rsd}_{\mathrm{x}, \mathrm{i}}$, beginning from the farthest downstream province going to the upstream province, under a certain water supply condition $(\mathrm{x}=1,2,3)$, is defined as:

$$
\begin{gathered}
R s d_{x, i}=\left(W u_{x}-\sum_{k} W_{x, i, k}\right) \quad \text { for } \mathrm{x}=1,2,3 \text { and } \mathrm{i}=1, \ldots, \mathrm{I} \\
\sum_{k} W_{x, i, k}=0 \quad \text { when } \mathrm{i}=1 \quad \text { for } \mathrm{x}=1,2,3
\end{gathered}
$$

\subsubsection{Proportional Sharing Rule (PSR)}

The water allocation rule for proportional sharing during a shortage allows each province to sustain the burden of water shortages proportionally. Under this arrangement, when shortages are shared, an $\mathrm{X} \%$ overall shortage of normal supplies reflects an equal $\mathrm{X} \%$ reduction of each province's full share under normal conditions. The remaining water supply after supplying provinces, using the proportional sharing of shortage allocation rule with higher priorities $\mathrm{Rsp}_{\mathrm{x}, \mathrm{i}}$, starting from the upstream province going to the farthest downstream under a certain water supply condition $(\mathrm{x}=1,2,3)$, is defined as:

$$
\begin{gathered}
R s p_{x, i}=\left(W u_{x}-\sum_{k} W_{x, i, k}\right) \quad \text { for } \mathrm{x}=1,2,3 \text { and } \mathrm{i}=1, \ldots, \mathrm{I} \\
\sum_{k} W_{x, i, k}=0 \quad \text { when } \mathrm{i}=1 \quad \text { for } \mathrm{x}=1,2,3
\end{gathered}
$$

The total paper rights by priority for all provinces is the sum of the percentage of water allocation rule of all provinces. The total paper rights constraint $T \mathrm{p}_{\mathrm{x}}$, under a certain water supply condition $(\mathrm{x}=1,2,3)$, is the sum of the total water rights percentages $\mathrm{Rp}_{\mathrm{x}, \mathrm{i}}$ of all provinces under the same conditions:

$$
T p_{x}=\sum_{i} R p_{x, i} \quad \text { for } \mathrm{x}=1,2,3
$$

The unknown water use assigned to $i^{\text {th }}$ province using one of the allocation rules, the UPR, the DPR, and the PSR, under specific water supply conditions (normal, dry, and drought water supply) are defined. The unknown water use $\mathrm{Wwu}_{\mathrm{x}, \mathrm{i}}$ assigned to $\mathrm{i}^{\mathrm{th}}$ province using $\mathrm{UPR}$, under a certain water supply condition $(\mathrm{x}=1,2,3)$, is defined as:

$$
W w u_{x, i}=\left(R p_{x, i} / T p_{x}\right) R s u_{x, i} \quad \text { for } \mathrm{x}=1,2,3 \text { and } \mathrm{i}=1, \ldots, \mathrm{I}
$$

The unknown water use $\mathrm{Wwd}_{\mathrm{x}, \mathrm{i}}$ assigned to the $\mathrm{i}^{\text {th }}$ province using DPR, under a certain water supply condition $(\mathrm{x}=1,2,3)$, is defined as:

$$
W w d_{x, i}=\left(R p_{x, i} / T p_{x}\right) R s d_{x, i} \quad \text { for } \mathrm{x}=1,2,3 \text { and } \mathrm{i}=1, \ldots, \mathrm{I}
$$

The unknown water use $\mathrm{Wwp}_{\mathrm{x}, \mathrm{i}}$ assigned to the $\mathrm{i}^{\text {th }}$ province using PSR, under a certain water supply conditions $(\mathrm{x}=1,2,3)$, is defined as:

$$
W w p_{x, i}=\left(R p_{x, i} / T p_{x}\right) R s p_{x, i} \quad \text { for } \mathrm{x}=1,2,3 \text { and } \mathrm{i}=1, \ldots, \mathrm{I}
$$

The cumulative water result, after water is assigned to the last province getting water, should match the total supply. Using the UPR, the cumulative water result $\mathrm{Cu}_{\mathrm{x}, \mathrm{i}}$ that is assigned to the last province obtaining water under a certain water supply condition $(x=1,2,3)$ is defined in equation 16 , which should match the total supply under the same condition $\mathrm{x}$.

$$
C u_{x, i}=\sum_{k}\left(W_{x, i, k}+W w u_{x, i}\right) \quad \text { for } \mathrm{x}=1,2,3 \text { and } \mathrm{i}=1, \ldots, \mathrm{I}
$$

Using DPR, the cumulative water result $\mathrm{Cd}_{\mathrm{x}, \mathrm{i}}$ that is assigned to the last province obtaining water under a certain water supply condition $(x=1,2,3)$ is defined in equation 17 , which should match the total supply under the same condition $\mathrm{x}$.

$$
C d_{x, i}=\sum_{k}\left(W_{x, i, k}+W w d_{x, i}\right) \quad \text { for } \mathrm{x}=1,2,3 \text { and } \mathrm{i}=1, \ldots, \mathrm{I}
$$

Using PSR, the cumulative water result $C \mathrm{p}_{\mathrm{x}, \mathrm{i}}$ is assigned to the last province receiving water under a certain water supply condition $(\mathrm{x}=1,2,3)$, which is defined in equation 18 , should match the total supply under the same condition $\mathrm{x}$.

$$
C p_{x, i}=\sum_{k}\left(W_{x, i, k}+W w p_{x, i}\right) \quad \text { for } \mathrm{x}=1,2,3 \text { and } \mathrm{i}=1, \ldots, \mathrm{I}
$$




\section{Results and Discussion}

The net farm income levels associated with irrigation for the Tigris and the Euphrates Rivers, predicted under each of the three water shortage sharing rules described in the mathematical model, are illustrated in Figures 2 and 3 . The proportional sharing of shortage water allocation rule (PSR) clearly performs with the highest level of flexibility for adapting to shortages. With PSR, all provinces receive water in a severe drought, thus, the water provides a positive advantage enabling the achievement of economic and food security. In contrast, under shortage conditions with UPR, water is used primarily by the upstream provinces and lower value crops will continue to be grown in the upstream provinces while downstream provinces receive lower amounts of water or no water at all. A similar phenomena is observed with DPR under shortage conditions where the downstream provinces receive the majority of water and lower value crops continue to be grown in the downstream provinces.

The net income losses under PSR during shortages have less economic cost caused by drought when compared with other types of water allocation rules due to the fact that PSR provides the opportunity for all provinces, under dry and drought conditions, to cultivate part of their farmland with higher economical crops. This reflected positively on the maximized net benefit in comparison to the UPR and DPR under the same water availability conditions.

For the dry water supply condition under PSR, farm net income is maintained at $62.3 \%$ and $72.3 \%$ of the maximum income under normal water availability conditions for the Tigris and Euphrates, respectively, as illustrated in Figures 2 and 3 . When considering PSR under drought water conditions, the farm net income drops approximately $62.2 \%$ for the Tigris River and $52.78 \%$ for the Euphrates River as compared to normal water supply conditions.

The downstream provinces suffer the most during water shortages under the common water right system typically used in Iraq (which is shown as UPR in the model). This is readily apparent from the model results presented in Figures 4 and 5. The results show that when drought occurs with UPR, the lands under production are going to be eliminated or reduced to lower values in downstream provinces. For example, the total planted area in Iraq with PSR is greater compared to the UPR water allocation rule by $10 \%$ and $21.4 \%$ under dry and drought conditions respectively for the Tigris River. This is because rather than the downstream provinces receiving little to none as compared to the other two water availability scenarios, PSR for the Tigris River ensures all provinces receive some water. However, the results for the Euphrates River with UPR result in greater values of the total planted area, approximately $23 \%$ and $54 \%$ greater for dry and drought conditions respectively, as compared to the results with the PSR. Nevertheless, the water is used more efficiently for net farm income with PSR as more water is focused on higher value crops.

When the dry water availability condition is applied, the model predicts that provinces that do not get water under UPR will obtain the water when DPR is applied with some exceptions, as illustrated in Figures 4 and 5. The provinces of Salaheldeen, Deyala, Baghdad-A, Karbala and Najaf received water under both UPR and DPR with different quantities since these five provinces are centrally located. Economically inefficient water allocation will occur with either the use of DPR or UPR since there is no motivation for specific provinces receiving the majority of water to change. Under an efficient water sharing system such as PSR, farmers would experience economic incentives to conserve water in a drought season and provide water to higher valued crops in downstream provinces like Thieqar, Meesan and Basra.

Water shadow prices were computed for both the Tigris and Euphrates River. Shadow prices reflect the marginal economic value per unit additional water and can be calculated for different water supplies, provinces, and water allocation systems. Salman et al. (2014), described the importance of shadow prices to assist farmers making investment decisions in developing alternative sources of water, such as groundwater pumping, water importation, or water conservation. Where the economic values of water are specified, these water shadow prices represent useful tools for identifying water policies (Rosegrant et al., 2000; Dopplera et al., 2002; Richmond et al., 2007).

For the Tigris River, the marginal value of water is approximately US\$64.75 for each additional 1,000 cubic meters of water, as illustrated in Figure 6, for both the dry and drought water availability scenarios. For the Euphrates River (Figure 7), the marginal value of water is approximately US $\$ 43.19$ for each additional 1,000 cubic meters of water under the dry water availability scenario and approximately US\$47.06 when the drought water availability scenario is adopted. Salman et al. (2014), demonstrated that the marginal value of water is approximately US\$32 for each additional 1,000 cubic meters of water in dry conditions and approximately US $\$ 93$ when severe shortage occurs. This study indicates that the process of adopting Tigris and Euphrates Rivers as individual basins results in the reduction of shadow prices under the drought condition while it provides similar values under the dry water availability condition. Under drought conditions, treating the Tigris and Euphrates Rivers as individual basins as performed in this study, provides greater flexibility leading to reduce shadow prices. 


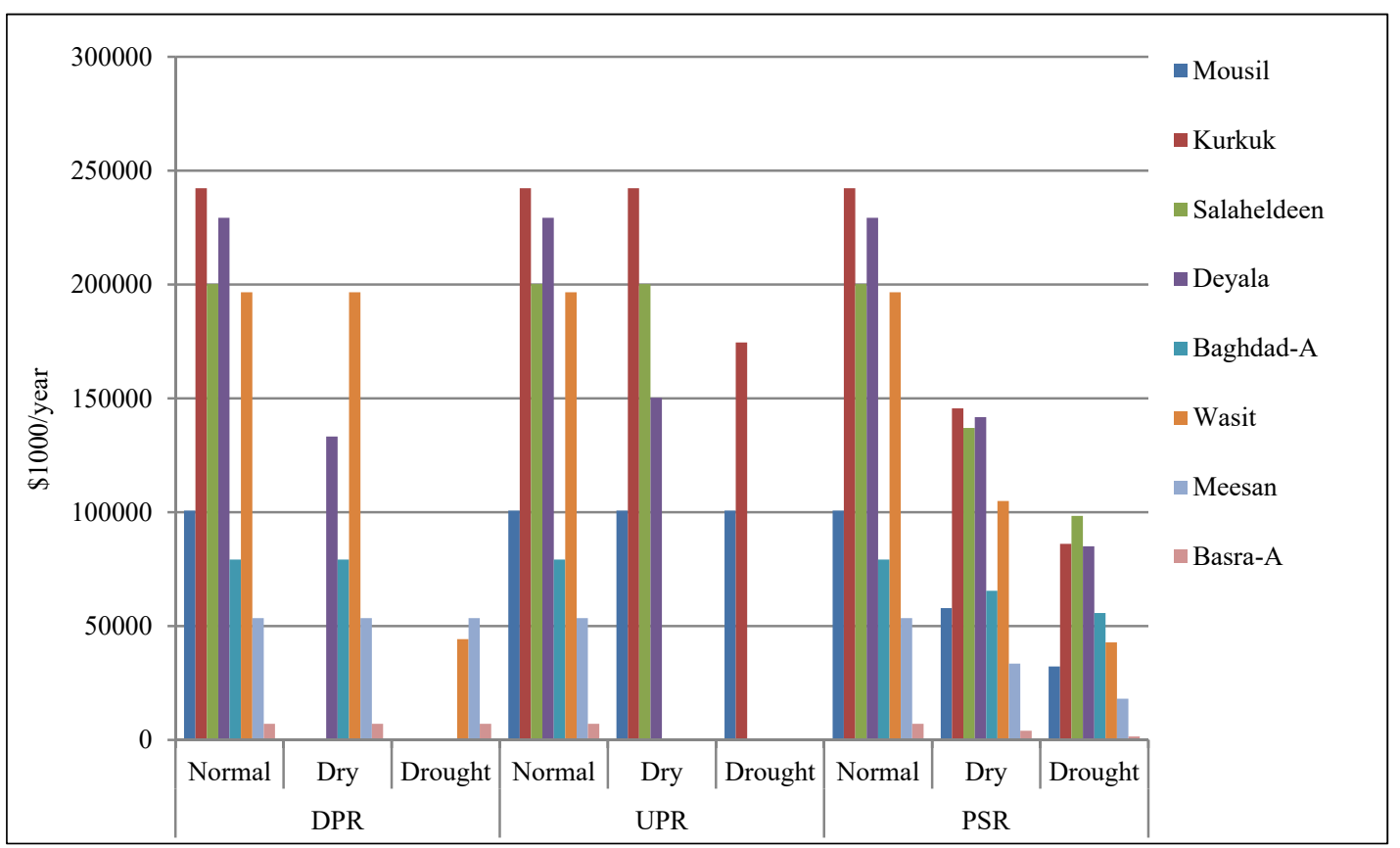

Figure 2. Model Results of the regional province income by water sharing arrangement, water supply, and province, Tigris River, Iraq ( $\$ 1000 /$ year)

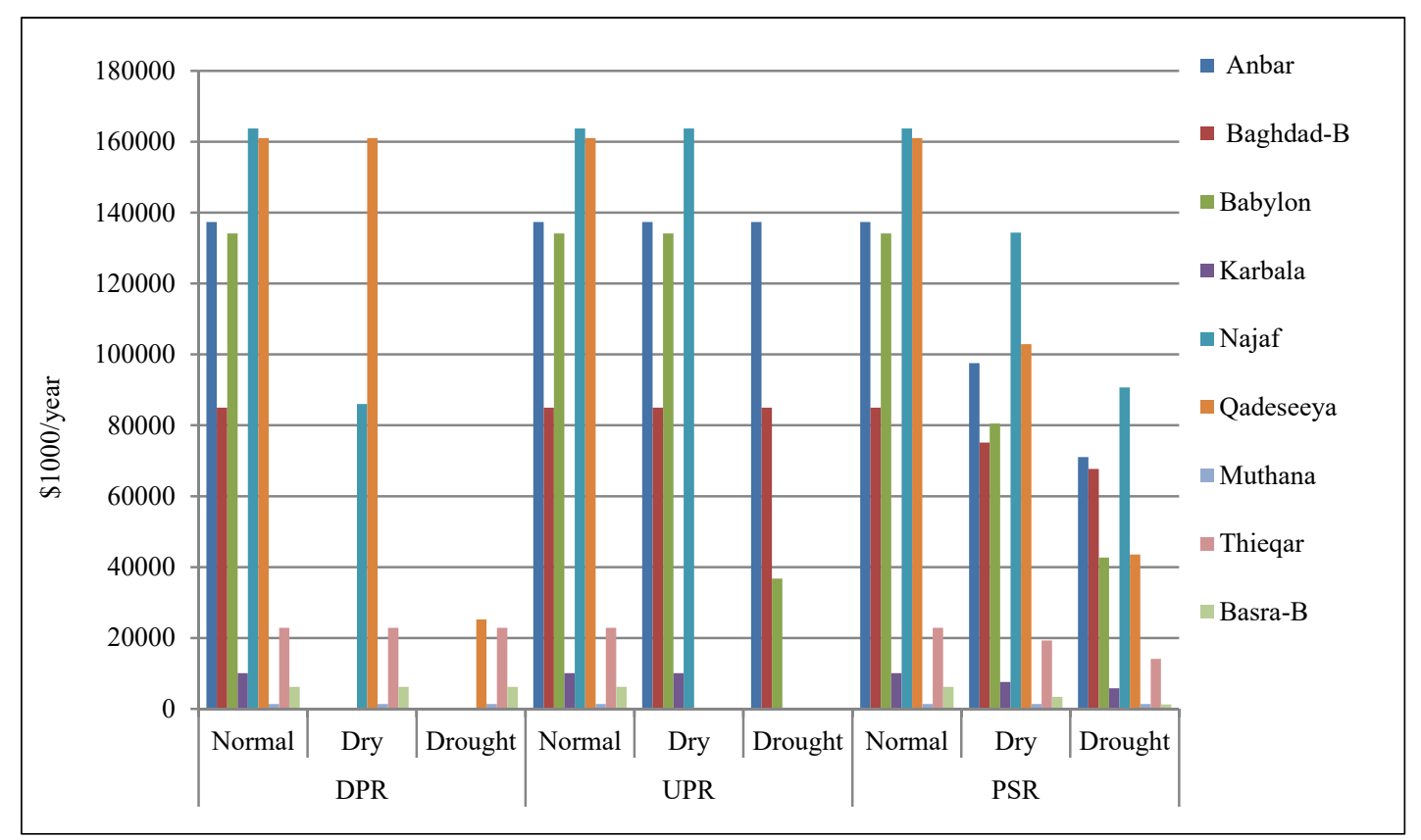

Figure 3. Model results of the regional province income by water sharing arrangement, water supply, and province, Euphrates River, Iraq (\$1000/year) 


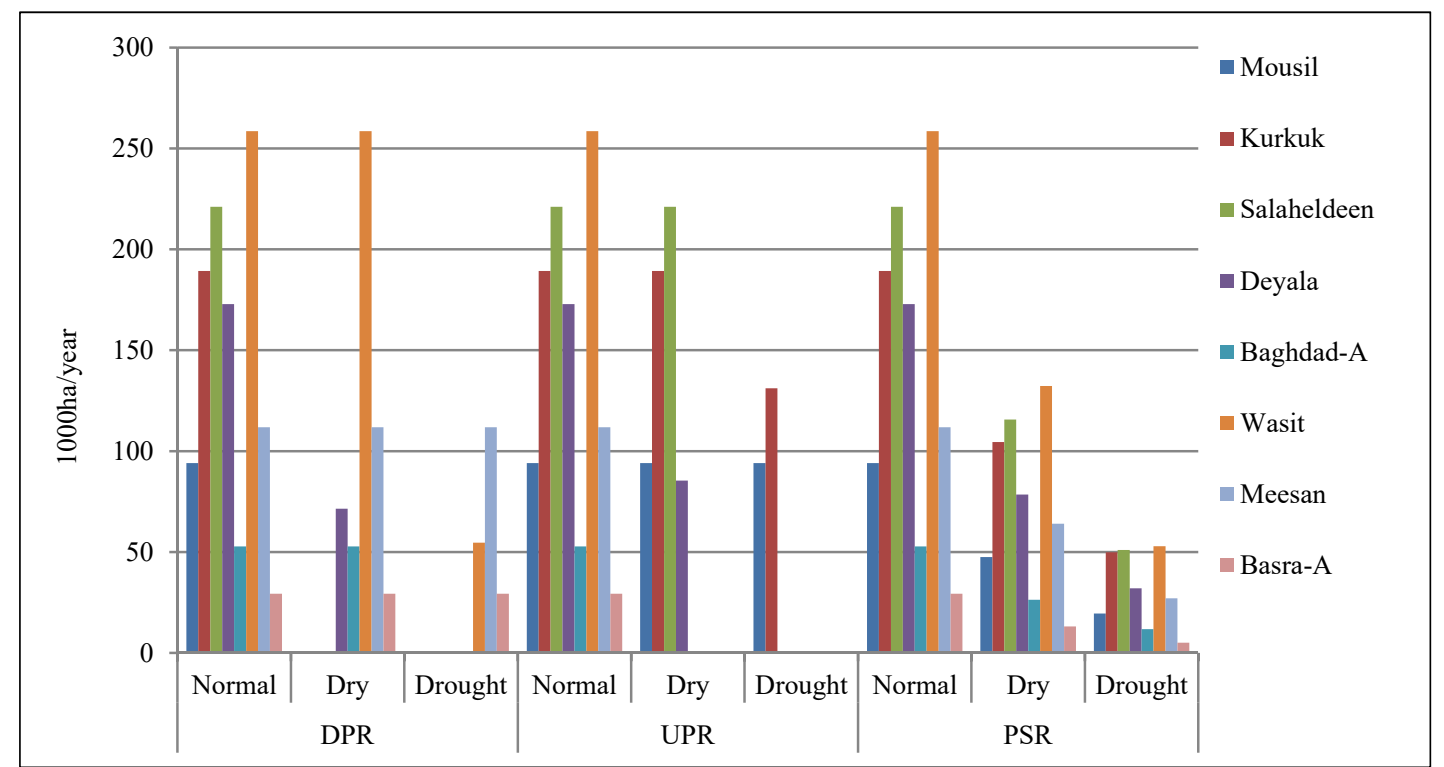

Figure 4. Model results of the irrigated land in production by province, crop, shortage sharing arrangement-water supply scenario, Tigris River Basin, Iraq, 2013 (1000ha/yr)

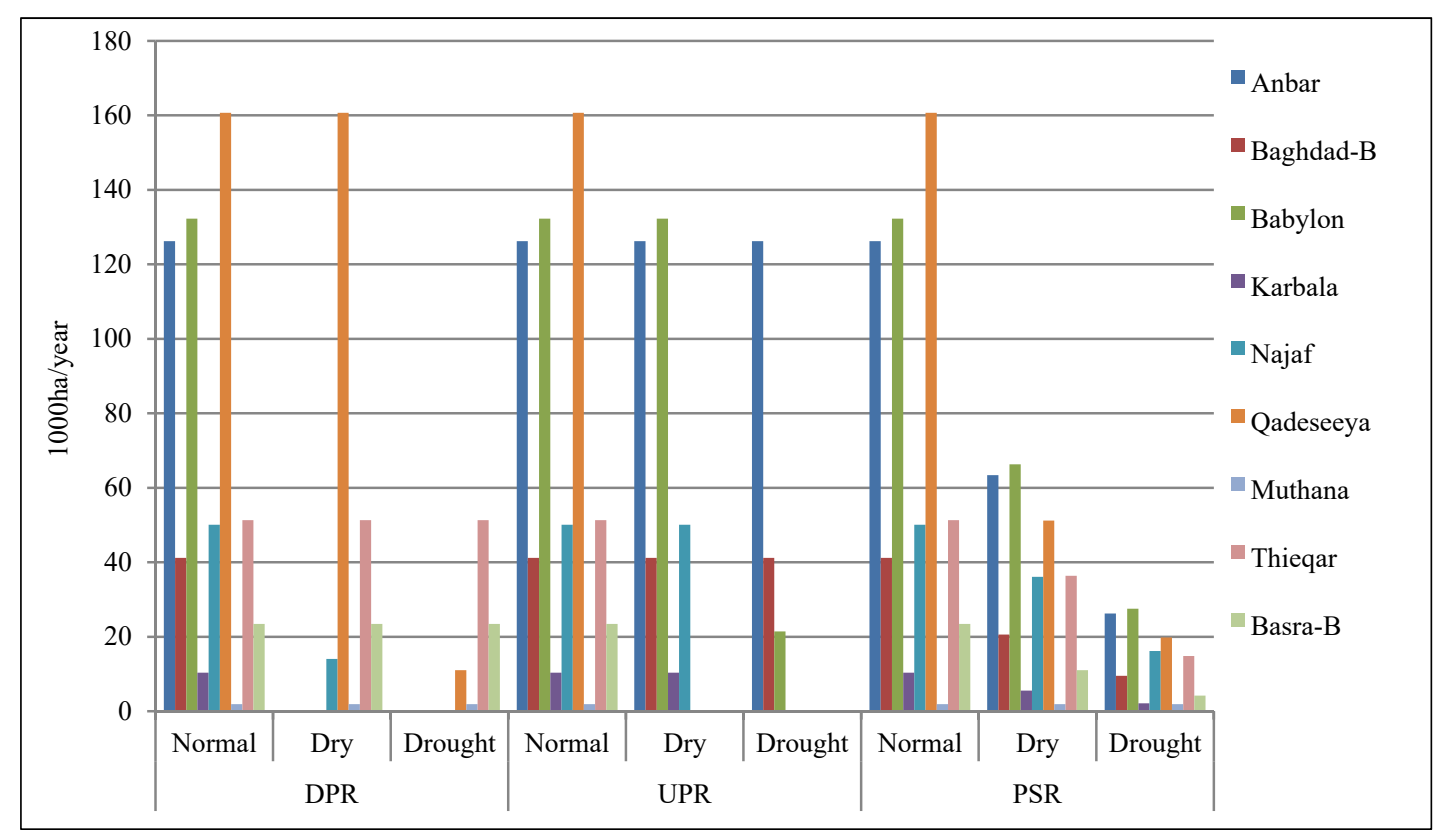

Figure 5. Model results of the irrigated land in production by province, crop, shortage sharing arrangement-water supply scenario, Euphrates River Basin, Iraq, 2013 (1000ha/yr) 


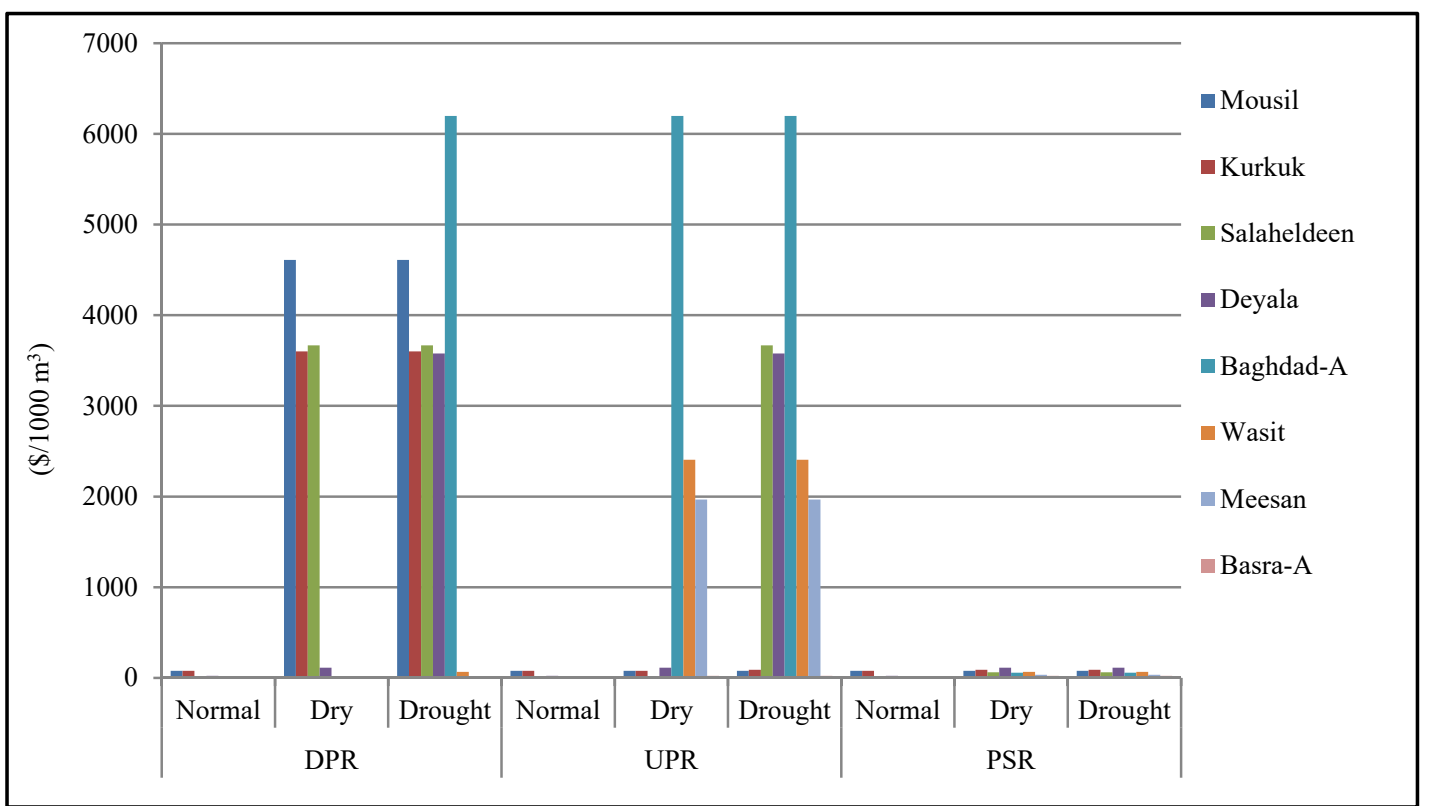

Figure 6. Model results of the shadow price of water by province, crop, shortage arrangement, and water supply scenario, Tigris River Basin, Iraq, $2013\left(\$ / 1000 \mathrm{~m}^{3}\right)$

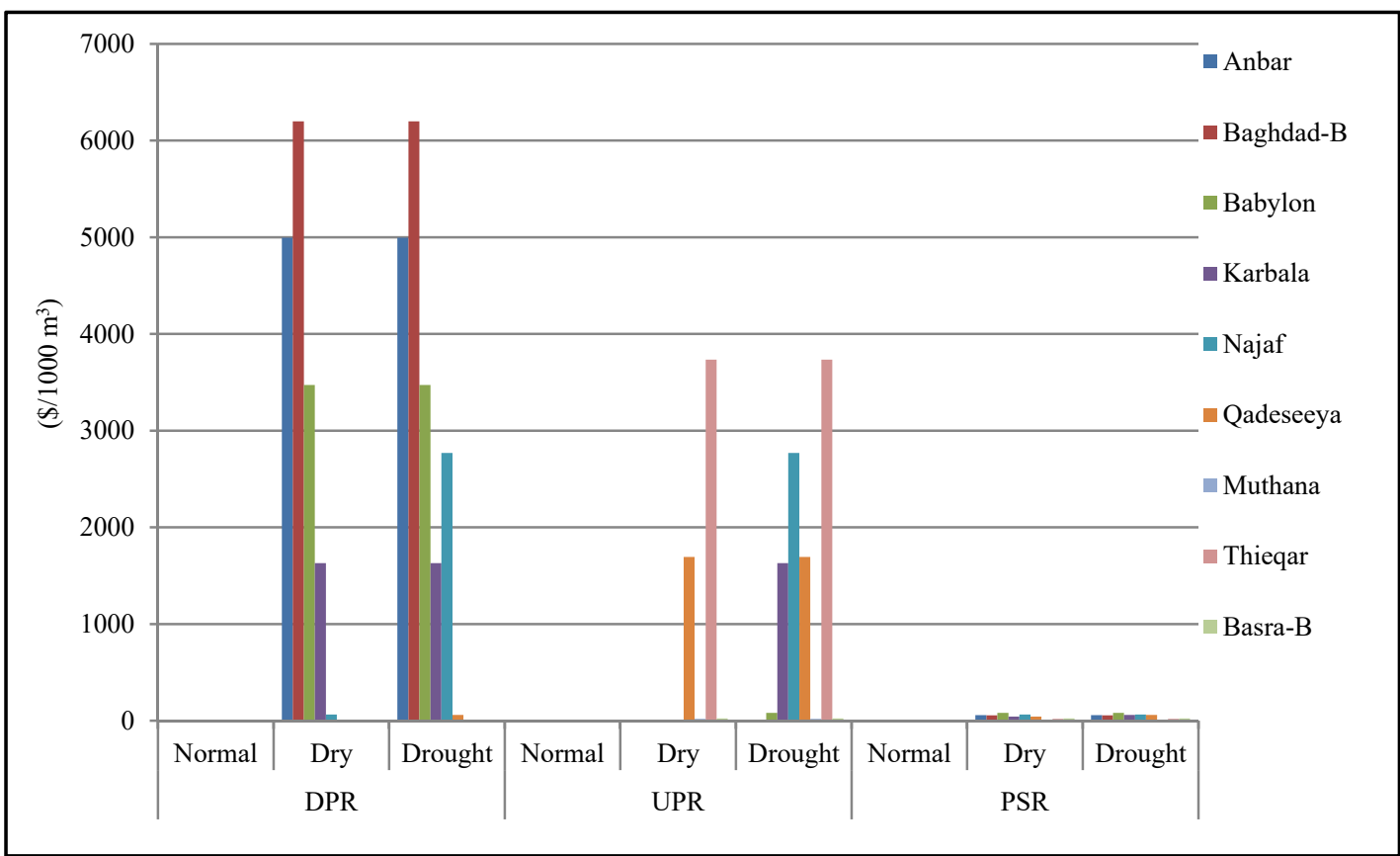

Figure 7. Model results of the shadow price of water by province, crop, shortage arrangement, and water supply scenario, Euphrates River Basin, Iraq, $2013\left(\$ / 1000 \mathrm{~m}^{3}\right)$

\section{Potential for Implementation of PSR in Iraq}

Due to the frequent droughts and water shortages which have occurred in Iraq in the last decade, the potentiality of using PSR is clear based on the model results. Iraq has the majority of the required hydraulic infrastructure to control and manage its water resources, thus implementation of further advanced and integrated water management strategies are feasible. Iraq has its own water legislation and laws which control and manage its water sources to allocate them for users. For instance, the 2008 law of the Ministry of Water Resources (MoWR) No. 50 provides the MoWR the ability to plan and invest Iraq's water resources for greater optimal usage. Furthermore, MoWR has the right to identify and develop water users to obtain optimal usage. Thus, MoWR has 
the full right to control the available water sources and to adopt an optimal water allocation strategy which assures the best investment of water resources.

Technically, the adoption of PSR needs advanced control technology to estimate water demand and to control water release to consumers to ensure water sharing for each one of the partnered provinces. The development of the recent water management system on both the administrative and technical aspects is one of the mandatory requirements not only for water conservation, but it is also required to satisfy the optimum distribution to maximize the potential benefits and to minimize water losses. Key investments are needed to satisfy that goal, which means more financial support for the water sector in Iraq to manage future's water issues. The elimination of ISIS and such other depleting factors will be necessary before key investments such as advanced control technology can be made.

Iraq is one of the richest water countries in the region; its people have the entrenched belief that the water supply will never be exhausted. Unfortunately, the water situation is becoming worse due to well-known reasons such as climate change, rapid population growth, dams in Turkey on the Tigris and the Euphrates Rivers, water pollution, water resource mismanagement, and the lack of awareness. Thus, adopting PSR as an alternative strategy, to allocate water among partnered provinces, will create wide debate and objections, especially among the riparian provinces. This may occur because of the belief that the river's upstream provinces have the right to obtain their full water share regardless of the downstream impacts. While on the agricultural farmlands level, the farmers who are on the upstream sections of the water distribution canals may object to the adoption of PSR if adopting such a strategy is optional. However, if it is mandatory, farmers may be persuaded that PSR assures fair distribution among them and their canal's tail farmers. Public acceptance of PSR requires a change in the public's perception of the facts regarding recent water shortages, which can be performed by the adoption of capacity building programs to educate the public. Capacity building programs should not only be limited to farmers, they should also include representatives of Iraqi provinces, local councils, and water related decision makers. The federal government currently has the right to apply laws which can appropriate the optimum distribution of water resources among riparian governorates. Due to Iraq having most of the required scientists and practical ingredients, in addition to the water infrastructure, Iraq has the appropriate environment to apply PSR by adopting developed approaches and technologies to handle the potential future shortages. An effective example of applied PSR water management strategy among riparian consumers is the one adopted allocating the Colorado River water resources in the United States. The management strategy allocates water among eight of the US states, in addition to Mexico, to handle the shortages proportionally (USBR, 2012). Thus, from this example we can determine that PSR in Iraq would benefit the agricultural sector.

\section{Summary and Conclusions}

A continuous challenge in water governance is studied through the recent research by examining how various water appropriation systems may affect profitability at both the farm and basin levels. Three water allocation systems are compared to measure their impacts on farm income under each of three different water supply scenarios. An optimization model was applied using general algebraic modeling system (GAMS) to maximize the net benefit of land production by computing the optimum farm income depending on the producing of different types of crops.

It is obvious that the proportional sharing of the shortage water allocation rule is the most economically feasible solution to be adopted because it provides the opportunity to all provinces to share water proportionally in order to share profits accordingly. It allowed for a $32 \%$ and $75 \%$ increase in the total farm income for the Tigris River under dry and drought supply conditions, respectively, as compared to UPR. In the same way, it allowed for $47 \%$ and $83.5 \%$ increase in the total farm income for the Euphrates River under dry and drought supply conditions, respectively, as compared to UPR. Even when severe droughts occurred, this water allocation rule secured some water for all provinces in a proportional sharing. It assures some water for all provinces in comparison to all for some, and none for others. On the other hand, the net income losses under the proportional allocation rule are less influenced by drought when compared with other types of water allocation rules.

For the case of dry water availability, farm net income is maintained at $62.25 \%$ and $72.32 \%$ of the maximum income, for the Tigris and Euphrates respectively, under PSR. Farm net income dropped from US\$1.11 billion and US $\$ 0.72$ billion in the normal supply scenario to US\$0.69 billion and US $\$ 0.52$ billion for Tigris and Euphrates River respectively, maintaining an impressive $62.25 \%$ and $72.32 \%$ of base income levels over all provinces when shortages are shared proportionally.

For the case of drought water availability considering the proportional shortage sharing rule, farm net income falls from US $\$ 1.11$ billion and US\$0.72 billion in the normal supply conditions to US $\$ 0.42$ billion and US\$0.34 billion annually for both of the rivers respectively. The flexibility in the use of the proportional sharing rule 
grants the incentive to all provinces to eliminate their lowest value crops from production, while continuing to cultivate the highest valued specialty crops that require specialized soils, management, and market access. With respect to the percent of lands in production, the same behavior is followed by provinces with cultivated farms. The conclusion of eliminating the low-income value crops and cultivating crops with a higher value is also described by Salman et al. (2014).

Finally, according to the computed shadow prices, water allocation rules, that are closest to economically efficient, produce shadow prices which are close to equal among provinces. This similarity of shadow prices is revealed clearly for the system of proportional sharing of shortages for both dry and severe water shortage conditions.

The results from this study are intended to provide guidance for decision makers in Iraq for potential future conditions where water supplies are reduced and demonstrate how it is feasible to adopt the PSR as an alternative and efficient water allocation rule due to its flexibility of providing fair water resource allocation in drought seasons. Adopting such an optimization modelling approach can assist decision makers, ensuring that decisions will benefit the economy by taking the advantage of the followed global experiences to control water allocations in Iraq especially with concern to diminished water supplies. There will be a need to utilize the modelling tools with changing constraints as water supplies, crops, and agricultural lands transform in the future.

\section{Acknowledgements}

Special thanks and gratitude to the Ministry of Higher Education and Scientific Researches-Iraq for the sponsoring and funding Ahmed A. Aljanabi's graduate study at Arizona State University. We would also like to show our gratitude to Professor Frank A. Ward of New Mexico State University for his comments on an earlier version of the manuscript and for allowing us to develop and advance his GAMS code for the NLP model applied in this study.

\section{References}

Al-Ansari, N. (2013). Management of water resources in Iraq: perspectives and prognoses. Engineering, 5(6), 667-684.

Al-Ansari, N. A., Knutsson, S., \& Ali, A. (2012). Restoring the Garden of Eden, Iraq. Journal of Earth Sciences and Geotechnical Engineering, 2, 53-88.

Al-Ansari, N., \& Knutsson, S. (2011). Toward prudent management of water resources in Iraq. Journal of Advanced Science and Engineering Research, 1, 53-67.

Babel, M. S., Das Gupta, A., \& Nayak D. K. (2005). A model for optimal allocation of water to competing demands. Water Resource Management, 19(6), 693-712.

Brown, T. C., Diaz, G. E., \& Sveinsson, O. G. B. (2002, July). Planning water allocation in river basins aquarius: a system's approach. In Proceedings of 2nd Federal Interagency Hydrologic Modeling Conference, Subcommittee on Hydrology of the Advisory Committee on Water Information.

Burton, M. A. (1994). A simulation of water allocation policies in times of water shortage. Irrigation Drainage Systems, 8(2), 61-81.

Dagnino, M., \& Ward, F. A. (2012). Economics of Agricultural Water Conservation: Empirical Analysis and Policy Implications. International Journal of Water Resources Development, 28(4), 577- 600.

Doppler, W., Salman, A. Z., Al-Karablieh, E. K., \& Wolff, H. P. (2002). The impact of water price strategies on the allocation of irrigation water: the case of the Jordan Valley. Agricultural Water Management, 55(3), 171-182.

Fang, S., Guo, P., Li, M., \& Zhang, L. (2013). Bilevel multiobjective programming applied to water resources allocation. Mathematical Problems in Engineering, 2013 (pp. 1-9).

Fotakis, D., \& Sidiropoulos, E. (2012). A new multi-objective self-organizing optimization algorithm (MOSOA) for spatial optimization problems. Applied Mathematics and Computations, 218, 5168-5180.

GAMS Development Corporation. (2013). General Algebraic Modeling System (GAMS), Release 24.2.1. Washington, DC, USA, 2013.

Iraqi Central Statistical Organization (ICSO). (2013). Retrieved from http://cosit.gov.iq/ar/agri-ind

Iraqi Ministry of Water Resources. (2013). Water Resources, Mosul dam. Retrieved July 25, 2015, from http://www.mowr.gov.iq/

Lu, H. W., Huang, G. H., \& He, L. (2011). An inexact rough-interval fuzzy linear programming method for generating conjunctive water-allocation strategies to agricultural irrigation systems. Applied Mathematics and Computations, 35, 4330-4340. 
Nord Nord West License. (2016). Creative Commons by-sa-3.0 de., Iraq dam location map.svg., The applicable license: http://creativecommons.org/licenses/bysa/3.0/de/legalcode. Retrieved from https://upload. wikimedia.org/wikipedia/commons/8/80/Iraq_adm_location_map.svg

Oxley, R. L., \& Mays, L. W. (2016). Application of an Optimization Model for the Sustainable Water Resource Management of River Basins. Water Resources Management. https://doi.org/10.1007/ s11269-016-1459-7

Oxley, R. L., Mays, L. W., \& Murray, A. (2016). Optimization Model for the Sustainable Water Resource Management of River Basins. Water Resources Management. https://doi.org/10.1007/s11269-016-1345-3

Paul, S., Nath, P. S., \& Nagesh, D.K. (2000). Optimal Irrigation Allocation: A Multilevel Approach. Journal of Irrigation and Drainage Engineering, 126, 149-156.

Richmond, A., Kaufmann, R. K., \& Myneni, R. B. (2007). Valuing ecosystem services: A shadow price for net primary production. Ecological Economics, 64(2), 454-462.

Rosegrant, M. W., Ringler, C., McKinney, D. C., Cai, X., Keller, A., \& Donoso, G. (2000). Integrated economic-hydrologic water modeling at the basin scale: the Maipo river basin. Agricultural economics, 24(1), 33-46.

Rothman, D., \& Mays, L. W. (2013). Water Resources Sustainability: Development of a Multi-Objective Optimization Model. Journal of Water Resources Planning and Management, 140(12). https://doi.org/10. 1061/(ASCE)WR.1943-5452.0000425,2014

Sadegh, M., Mahjouri, N., \& Kerachian, R. (2010). Optimal Inter-Basin Water Allocation Using Crisp and Fuzzy Shapley Games. Water Resources Management, 24, 2291-2310.

Saleh, D. K. (2010). Stream Gage Descriptions and Streamflow Statistics for Sites in the Tigris River and Euphrates River Basins, Iraq. Data Series 540, U.S. Department of Interior, U.S. Geological Survey.

Salman D. A., Saud, A., Amer, S. A., \& Ward, F. A. (2014). Water Appropriation Systems for Adapting to Water Shortages in Iraq. Journal of the American Water Resources Association, 50(5), 1208-1225

Salman, A. Z., Al-Karablieh, E. K., \& Fisher, F. M. (2001). An inter-seasonal allocation of irrigation water system. Agricultural Systems, 68, 233-252. https://doi.org/10.1016/S0308-521X(01)00010-5

Shangguan, Z. P., Shao, M. G., Horton, R., Lei, T. W., Qin, L., \& Ma, J. Q. (2002). A model for regional optimal allocation of irrigation water resources under deficit irrigation and its applications. Agricultural Water Management, 52, 139-154.

Shean, M. (2008). Iraq: drought reduces 2008/09 winter grain production. United States Department of Agriculture, Foreign Agricultural Service.

UNDP. (2009). UNDP Helps Drought-Stricken Iraq Combat Effects of Climate Change. United Nations Development Programme. Retrieved June 20, 2017, from http://www.undp.org/content/undp/en/home/ presscenter/articles/2009/12/16/undp-helps-drought-stricken-iraq-combat-effects-of-climate-change.html

UNEP. (2001). The Mesopotamian Marshlands: Demise of an Ecosystem, Early Warning and Assessment Technical Report no. 3, UNEP/DEWA/TR.01-3, (Geneva: UNEP).

USBR. (2012). Colorado River Basin Water Supply and Demand Study. United States Bureau of Reclamation, Lower Colorado Region, United States Department of the Interior, Water Power Resources Service, Lower Colorado Region, \& United States Bureau of Reclamation.

Vaghefi, S. A., Mousavi, S. J., Abbaspour, K. C., Srinivasan, R., \& Arnold, J. R. (2015). Integration of hydrologic and water allocation models in basin-scale water resources management considering crop pattern and climate change: Karkheh River Basin in Iran. Regional environmental change, 15(3), 475-484.

Wang, Z., Yang, J., Deng, X., \& Lan, X. (2015). Optimal water resources allocation under the constraint of land use in the Heihe River Basin of China. Sustainability, 7(2), 1558-1575.

You, J., Gan, Z., Gan, H., \& Jia, L. (2011). Development and application of water allocation model based on ET-control. IAHS-AISH publication, 198-205.

\section{Copyrights}

Copyright for this article is retained by the author(s), with first publication rights granted to the journal.

This is an open-access article distributed under the terms and conditions of the Creative Commons Attribution license (http://creativecommons.org/licenses/by/4.0/). 